\title{
IMPERIALISTIC FANTASIES
}

\section{AND THE FUTURE OF THE UNIVERSITY}

Shien-Hauh Leu

Doctoral Student, ASPECT Program, Virginia Tech

slue@vt.edu

The university as it is commonly perceived is perhaps in some form of crisis. One must, nonetheless, immediately confront at least two interrelated problems in order properly understand the issue. What is the university? And, moreover, what is crisis? Joseph Pitt engages these issues directly, based on certain assumptions about the meaning of such questions, which thus appear to have a prediscursive consistency that has been obscured or distorted by unnatural machinations, and the proper realization of which must be restored through concerted efforts of demystification. I offer an admittedly abbreviated and perhaps even polemical response (given the constraints of this response) that suggests Pitt's proposed solution does not resolve the fundamental structural tendencies, but merely externalizes, outsources and postpones engagement with the underlying antagonisms, one of which stems from the constitutive violence of the university as an (Althusserian) ideological state apparatus.

The common temptation is to define the university retroactively. The university might therefore be defined descriptively insofar as its present characteristics can be catalogued and represented. This approach is perhaps not entirely satisfactory since the university as such can never really be in crisis; it is simply what it is. If there is to be a crisis, then, it seems necessary to take a normative approach by which the present state of the university is compared to predefined point of reference. It would also seem 
that this point must be located somewhere in the past, rather than the future, since only a preexisting framework could authorize the notion of a present crisis, whereas a framework yet to come would only suggest that the university as such had never actually existed. However, an analysis of the conception the university which allows the present situation to be perceived as a crisis underscores simultaneously the problematic of defining the university and the very notion of crisis.

The need to locate authorization from the past is well captured by Frank Donoghue observation regarding the apparent crisis in higher education (especially in the humanities). ${ }^{1}$ Donoghue's point is not to dispute the claim that there is some kind of antagonism in progress, but rather to assert that the so-called crisis "has been like this for a very long time." ${ }^{2}$

Moreover, Donoghue reminds us that the so-called crisis is not the result of some extrinsic disturbance. Rather, the element known as crisis, which is perceived as the secret ingredient which obstructs the restoration of a pure university uncontaminated by non-academic politico-economic forces, has been with the university from the very beginning. The temptation is to imagine, for example, a corporate ideology that encroaches upon academia-some scholars thus "imply that universities and corporations were once entirely separate spheres before corporate thinking began to pollute academic organizations." 3 However, such a conception of the "pure" ideal university under siege is a properly fantasmatic notion that retroactively intervenes to restructure the empirical reality. ${ }^{4}$

\footnotetext{
1 "Humanists have perhaps always waxed histrionic on this topic." Donoghue proceeds to quote Hayward Keniston's address at the Modern Language Association's annual convention in December 1952: "Ladies and gentlemen: it is time for an an awakening . . For a restoration of the relevance of our discipline to the life of our day. For our day is a day of crisis." Frank Donoghue. The Last Professors: The Corporate University and the Fate of the Humanities. (New York: Fordham UP, 2008), 1.

2 Ibid., 1.

${ }^{3}$ Ibid.,2.

4 "[Corporations] and universities have been prominent features of American society since the aftermath of the Civil War, when both kinds of institutions were born. They have always
} 
Another symptom of the desire to locate an external source of perversion is the distortion of a properly genealogical understanding of complicity with various enabling preconditions. This gesture seems unnecessary except to facilitate the misrecognition of the originary violence that inherently produces the apparent distortions. One of the cornerstone disciplines of the American university, for example, is the field of English literature, which inherits a canon that is constituted precisely through a combination of imperialistic expansion and class warfare. Terry Eagleton notes how English literature sustains the ideological function on which religion no longer held its monopoly. ${ }^{5}$ The obvious solution to such a crisis is to find an alternative ideological device, and literature is precisely the answer. ${ }^{6}$ As such, one cannot simply ignore the inherently political dimension of the founding gesture of English literature as it is commonly understood nowadays.

Other disciplines likewise share such ideological complicity. David Harvey notes, for example, the imperialistic dimension of the field of economics:

[By] 1990 or so most economics departments in the major research universities as well as the business schools were dominated by neoliberal modes of thought. The importance of this should not be underestimated. The US research universities were and are training grounds for many foreigners who take what they learn back to their countries of origin- -the key figures in Chile's and Mexico's adaptation to neoliberalism were US-trained economists for example -

intersected, sometimes in very concrete ways: businessmen began serving on university boards of trustees as early as the 1870s; the University of Pennsylvania's Wharton School first offered an academic credential in business administration in 1881" (ibid., 2-3).

5 "By the mid-Victorian period, this traditionally reliable, immensely powerful ideological form was in deep trouble [...] This was particularly worrying for the Victorian ruling class, because religion is for all kinds of reasons an extremely effective form of ideological control." Terry Eagleton. Literary Theory. (Malden, MA: Blackwell. 1996), 20.

6 "As religion progressively ceases to provide the social 'cement', affective values and basic mythologies by which a socially turbulent class-society can be welded to- gether, 'English' is constructed as a subject to carry this ideological burden from the Victorian period onwards" (ibid 21). 
as well as into international institutions such as the IMF, the World Bank, and the UN. ${ }^{7}$

Of course, one might argue that this modus operandi goes against the university proper. Yet the key lesson is that university has long been sustained by precisely such objectionable practices. This awareness should be perhaps be taken as an invitation to assess the real meaning of the university, rather than to withdraw further into a mythical notion of an ideal university of dubious authenticity. The solution, then, is precisely not to locate the present crisis of the university as an imbalance precipitated by some external intrusion. One should acknowledge the structural function of the university as inherently part of what might be referred to as a core component of the Ideological State Apparatus in its properly Althusserian sense. The desire to locate and confine the various pathologies of the university within a specific dimension perceived as alien to the university proper recalls Althusser's insistence on the irrelevance of the distinction between the public and private sphere in relation to ideology. ${ }^{8}$ While many ideological apparatuses appear to operate entirely in the private sphere, they nonetheless serve critical functions for the state, and the proper critique must engage the actual (state) function rather than the ostensible designation (of public or private). The university should likewise be examined based on its actual function rather than its ideal designation.

To see the crisis of the university as an injury symptomatic of an external violation to its original integrity is to miss the originary violence that comprises its constitutive founding gesture. As Walter Benjamin writes, "[the] tradition of the oppressed teaches us that the 'state of emergency' in which we live is not the exception but the rule." ${ }^{9}$ The precondition for the dichotomy through which the pure, uncontaminated notion of an

\footnotetext{
${ }^{7}$ David Harvey. A Brief History of Neoliberalism. (Oxford: Oxford UP, 2005), 54.

${ }^{8}$ Louis Althusser. Lenin and Philosophy and Other Essays. Trans. Ben Brewster. (New York: Monthly Review P, 1971), 144.

${ }^{9}$ Benjamin, Walter. Illuminations. Ed. Hannah Arendt. Trans. Harry Zohn. (New York: Harcourt Brace, 1968), 259.
} 
ideal university is perpetuated relies precisely on outsourcing the dirty work of its constitutive violation. By rendering the imperialistic machinations of the university as an anomaly from without, it only appears that the university proper could have been and must have been distinct from such later deviations. But one should be suspicious of such convenient demarcations, and note especially the class dimension which informs the dichotomy.

From whose perspective would the university appear as a sacred, inviolable, and perhaps, more importantly, stable enterprise, a perspective which enables an awareness of acute (rather than chronic) crisis? Certainly not of those who have consistently been the target of the oppressive reach of the university. Moreover, there is no need to look outside of the university for such victims. Faculty, staff and students alike experience daily the systemic oppression of the university. Here one should rather find a constant state of emergency and violation that is actively produced by and characteristic of the university. Only ruling class ideology, therefore, has an interest in maintaining the illusion of the university as an idllic sanctum under siege from external corruption. Here one should defer to Nietzsche:

[Life] operates essentially, that is in its basic functions, through injury, assault, exploitation, destruction and simply cannot be thought of at all without this character. One must indeed grant something even more unpalatable: that, from the highest biological standpoint, legal conditions can never be other than exceptional conditions. ${ }^{10}$

The "ideal" condition is inherently the exceptional condition. The legitimacy of the actually existing equilibrium is fundamentally sustained by violations that are authorized through a procedural sleight of hand. The lack of formal transgression dissimulates itself as a lack of de facto violation. Indeed, the characteristic violations perpetrated by the university are systematically rearticulated as either legitimate procedures or as

\footnotetext{
${ }^{10}$ Nietzsche, Friedrich. On the Genealogy of Morals and Ecce Homo. Trans. WalterKaufmann. (New York: Random House, 1967), 76.
} 
inevitable concessions in the face of crisis. The appropriate response, then, is to challenge the right to define the meaning of crisis from a tendentious class orientation. One may begin by noting the precondition that enables the articulation of crisis as an exceptional event rather than a persistent condition is already a mythical construction that disguises an imperialistic modus operandi. The fantasy presupposes a mythical university that is free of contamination. Such an ideal university, however, is largely inconsistent with the empirical reality of the university. As such, an effective response must account for the ideological dimension that structures the mythical edifice.

The university as such can be seen as a manifestation of the ever-elusive objet petit $a$, the empty cause of desire that's always yet to come. Indeed, it is the "unattainable $\mathrm{X}$, the object-cause of desire" ${ }^{11}$ which cannot be located in our positive reality. It is at this ideological level where we must resist the mythical dimension of the university. ${ }^{12}$ Crucially, it is insufficient to merely point out the discrepancy between the ideal university as objet petit a and it's empirically identifiable reality. One must take the further step and neutralize the ideology that always restructures and reappropriates the positive reality. A constant state of emergency, as we have observed, can be ideologically restructured as an exceptional event. Without a fundamental perspectival reorientation, there can be resistance to the misrecognition of systemic violence as accidental interruption. Indeed, such an ideological distortion structures one of the core functions of the university. There is thus a sense in which the ideal university serves as a repository and gatekeeper of knowledge.

One must ask the obvious epistemological question that arises in the process of one the main functions of the university: in the transmission of knowledge to students, what is the status of assessment? Indeed, what does the standard model of assessing student progress actually reflect? The critical gesture is to insist that any answer is

\footnotetext{
${ }^{11}$ Slavoj Žižek. The Sublime Object of Ideology. (London: Verso, 1989), 96.

${ }^{12}$ As Žižek puts it "we search in vain for it in positive reality [precisely] because it has no positive consistency" (ibid., 95).
} 
invariably overdetermined by the question, and underscore the tendentious assumptions in articulating the university as the guardian of knowledge.

A primary technology mobilized to assert the university's role as guardian of knowledge is teaching, but the fundamental difficulty in negotiating the inextricable link between teaching and assessment is often systemically ignored or co-opted. Standards of assessment necessarily contaminate the teaching process, affecting both the methodological approach and substantive content. The unfortunate consequence is that learning potentially becomes only an accessory to passing the assessment. The assumption behind most forms of assessment, moreover, is its adequacy in gauging student learning outcomes. This may be true insofar as the student acquires the specific ability to pass a given assessment, but this result does not explicitly acknowledge its constitution as a combination of factors which includes more than the activities in the classroom and assignments directly related to coursework.

It is also necessary to remember that the outcome of any assessment is never just a reflection of the student's learning, but it is also symptomatic of the instructor's teaching-which, at the same time, is tied to systemic constraints imposed by expectations in the process of assessing student learning. One must see this tripartite relationship as a dialectical system that cannot exist outside of its symbiotic constitution.

Systemic influences beyond the classroom must be acknowledged as wellstudents are not just burdened with coursework, but also with life responsibilities; the wide variance of class backgrounds means certain students will inevitably face greater workloads outside of their academic pursuits. The fantasy of pure assessment in which actors are putatively uncontaminated by such structural distortions only reifies and naturalizes the already-skewed outcome while pandering to an ideology of procedural equality.

Assessment, therefore, can be interpreted as neither a pure indicator of student performance, instructor performance nor systemic tendencies. Teaching is a likewise hybrid activity that requires as much attention to the titular component of teaching as it does to the other constituents that comprise the undertaking. In other words, the very 
act of gatekeeping always already contaminates knowledge itself, especially insofar as only the knowledge sanctioned by particular modes of examination are considered authorized.

Such an orientation does not necessarily seek to challenge the objective collective knowledge available to humanity, but it does challenge the monopoly on knowledge-or the gatekeeper role-the university attempts to impose through its mechanisms of authorization and legitimization. If there ever was a crisis of university, it is high time to embrace it as an opportunity of change, and, from a subaltern perspective, to create a "real state of emergency"13 from which longstanding systemic pathologies can be addressed. 